\title{
Levels of organochlorine pesticides residues in meat
}

\author{
*G. Darko; S. O. Acquaah \\ Department of Chemistry Kwame Nkrumah University of Science and Technology Kumasi, Ghana \\ Received 23 February 2007; revised 3 July 2007; accepted 15 August 2007; available online 1 September 2007
}

\begin{abstract}
Concentrations of organochlorine pesticides (Lindane, Aldrin, Dieldrin, Endosulfan, DDT and DDE) residues in beef samples from the Kumasi and Buoho abattoirs in Ghana were determined using gas chromatography. Organochlorine residues were found in all the samples. The average concentration of lindane in beef fat samples from Kumasi was $4.03 \mu \mathrm{g} / \mathrm{kg}$ and $1.79 \mu \mathrm{g} / \mathrm{kg}$ in beef fat from Buoho. The average levels of lindane were $2.07 \mu \mathrm{g} / \mathrm{kg}$ for lean meat samples from Kumasi abattoir and $0.60 \mu \mathrm{g} / \mathrm{kg}$ in lean meat samples from Buoho. Endosulfan concentration in meat samples from Buoho was $2.28 \mu \mathrm{g} / \mathrm{kg}$ in the fat and $0.59 \mu \mathrm{g} / \mathrm{kg}$ in the lean beef. 1,1-dichloro-2,2-bis(pdichlorodiphenyl)ethylene (DDE) recorded mean concentrations of $118.45 \mu \mathrm{g} / \mathrm{kg}$ in beef fat and $42.93 \mu \mathrm{g} / \mathrm{kg}$ in lean beef samples from Kumasi abattoir. Beef samples from Buoho had DDE concentration of $31.89 \mu \mathrm{g} / \mathrm{kg}$ in the fat and $5.86 \mu \mathrm{g} /$ $\mathrm{kg}$ in the lean beef. 1, 1, 1-trichloro-2, 2-bis-(4'-chlorophenyl) ethane (DDT) recorded an average concentration of $545.22 \mu \mathrm{g} / \mathrm{kg}$ in beef fat and $18.85 \mu \mathrm{g} / \mathrm{kg}$ in lean beef samples from Kumasi abattoir. The average concentration of DDT in beef fat from Buoho was $403.82 \mu \mathrm{g} / \mathrm{kg}$ but lean meat samples from the same sampling site recorded mean concentration of $10.82 \mu \mathrm{g} / \mathrm{kg}$ for DDT. Although, most of the organochlorine residues detected were below the maximum limits set by the FAO/WHO, bioaccumulation of these residues is likely to pose health problems in higher organisms like human beings.
\end{abstract}

Key words: Organochlorine, pesticides, residues, beef

\section{INTRODUCTION}

Pesticides have been used in the public health sector for disease vector control and in agriculture to control and eradicate crop pests for the past several decades in Ghana (Clarke, et al., 1997). However, there has been a rapid rise in the quantity of pesticides used in agriculture over the past ten years (Hogson, 2003). The majority of pesticides used in agriculture are employed in the forest zones located in the Ashanti, Brong Ahafo, Western, and Eastern Regions of the country (Amoah, et al., 2006). Organochlorine pesticides are widely used by farmers because of their effectiveness and their broad-spectrum activity. Lindane is widely used in Ghana on cocoa plantations, on vegetable farms, and for the control of stem borers in maize. Endosulfan, marketed as thiodan, is widely used in cotton growing areas on vegetable farms, and on coffee plantations (Gerken, et al., 2001). Organochlorine pesticides such as DDT, lindane and endosulfan are also employed to control ectoparasites of farm animals and pets in Ghana (Ntow et al., 2006). In the public health arena, pesticides, (primarily temephos) have been used by the Onchoccerciasis Programme in the Volta Basin for

*Corresponding Author Email: godfreddarko@yahoo.com Tel.: +233 243239 354; Fax: +233 5140808 control of black flies (Simulium spp.) which transmit Onchocerciasis (African river blindness) to human beings and for control of domestic pests, e.g. cockroaches, flies, mosquitoes, ectoparasites including ticks, and other insects. Pesticides have also been used to control black flies along the banks of the Tano and Pra Rivers. (Ntow, 2005). Pesticide residues in food items have been a concern to environmental and consumer groups of their wide spread use. Most pesticides, especially, the organochlorines are very resistant to microbial degradation. They can, therefore, accumulate in human body fats and the environment posing problems to human health (Ejobi, et al., 1996). Through their persistence and lipophilicity, the pesticides and their residues may concentrate in the adipose tissues and in the blood serum of animals leading to environmental persistence, bioconcentration and biomagnification through the food chain. Although the organochlorines are banned from importation, sales and use in Ghana, there are evidence of their continued usage and presence in the ecosystem. Work already done in some farming communities in the Ashanti Region of Ghana and some other countries indicate the presence of Organochlorine pesticide residues in fish (Osafo and Frempong, 1998), vegetables, water, 
sediments, mother's milk, blood samples (Ntow, 2001). Meat may contain high levels of pesticide residues as a result of concentration of residues in the tissues following cattle dipping or vector control or when they feed on feedstuffs contaminated with these chemicals. Because these chemicals are toxic to living organisms, increased accumulation in the food chain may pose serious health hazards to the general populace (Jayashree and Vasudevan, 2007). In order to avert any environmental and health disaster, it is essential to put up mechanisms for monitoring of residues levels in the ecosystem as well as the food chain.

\section{MATERIALS AND METHODS}

Beef samples were taken from the Kumasi Abattoir and Kumasi Meat Packaging Company (KUMPACO) at Buoho in Ghana. Fifty samples were randomly taken from the Kumasi and Buoho abattoirs. Samples were wrapped in aluminum foil, placed in an ice-chest containing ice and sent to the laboratory for analysis. Sampling was done in two batches; first batch of samples were taken between the months of May and July, 2004 and the second batch, between December 2005 and March 2006. Raw meat sample (10 g) was homogenized using a Waring blender. The sample was mixed with 10 g sodium sulphate and then transferred to a $250 \mathrm{ml}$ separatory funnel. Hexane $(20 \mathrm{~mL})$ was added followed by $100 \mathrm{~mL}$ acetonitrile saturated with hexane. The mixture was shaken for about one minute. The actonitrile was drained into a one $1 \mathrm{~L}$ separatory funnel. The mixture was further extracted three times with 50 $\mathrm{ml}$ portions of acetonitrile. The extracts were combined, washed with $500 \mathrm{~mL}$ distilled water followed by $40 \mathrm{~mL}$ saturated sodium chloride solution and $50 \mathrm{ml}$ hexane. The mixture was then allowed to stand for 30 mins. and the aqueous layer drained into another $1 \mathrm{~L}$ separatory funnel and extracted with further $50 \mathrm{~mL}$ hexane. All the hexane extracts were combined and passed through a plug of $10 \mathrm{~g}$ sodium sulphate into a flask. The solvent was evaporated using a rotary evaporator.

The residue was dissolved in $10 \mathrm{~mL}$ methanol and diluted with $25 \mathrm{~mL}$ of distilled water. A portion (3.5 mL) of this solution (equivalent to $1 \mathrm{~g}$ of meat sample) was taken for pesticide residue analysis after clean up. In order to remove co-extractives from the analyte, the extracts were cleaned up using pre-conditioned C-18 Solid Phase Extraction bond columns and residues recovered by eluting 3 times with $5 \mathrm{~mL}$ portions of hexane. A Shimadzu GC - 9A Gas Chromatograph equipped with a ${ }^{63} \mathrm{Ni}$ Electron Capture Detector and SPB - 608 (15 m x 0.5mm film) Capillary Column was used in the analysis. All chemicals were purchased from $\mathrm{BDH}$ and were pesticide residue grade. Solid phase extraction (SPE) bond elut, (C-18, 3 cc / $500 \mathrm{mg}$ ), and organochlorine pesticides residues standards, (Lindane, aldrin, dieldrin, p,p-DDE, p,p-DDT, and endosulfan) were purchased from Varian Inc, USA. The Gas Chromatographic analysis was performed under the following conditions: The detector temperature was $320^{\circ} \mathrm{C}$. The injector temperature was $220^{\circ} \mathrm{C}$ and the column temperature was $160^{\circ} \mathrm{C}$ (isothermal). Carrier gas was helium at a flow rate of $30 \mathrm{~cm} / \mathrm{sec}$. $1 \mathrm{~mL}$ of sample was injected into the GC. In the GC analysis, peaks were identified by comparing their retention times with those of the standards under the same injection conditions. The samples were also injected under the same conditions as done with the standards. The peak areas of the various peaks whose retention times coincide with the standards were extrapolated on their corresponding calibration curves to obtain the concentrations. Under the experimental conditions, the retention times for Lindane, Aldrin, Endosulfan, p,pDDE, Dieldrin, and p,p-DDT were 0.89, 2.72, 4.55, 6.23, 9.62 , and 12.36 minutes respectively.

\section{RESULTS}

Meat from Kumasi and Buoho abattoirs were analyzed for organochlorine pesticide (Lindane, Aldrin, Dieldrin, Endosulfan, DDT and DDE). Concentrations of the various residues in each sample were calculated (in $\mathrm{mg} / \mathrm{kg}$ sample). The average concentration of each pesticide was compared to the WHO maximum residue limits (MRLs).

Table 1: Levels of pesticide residues in beef fat from Kumasi abattoir $(\mu \mathrm{g} / \mathrm{kg})$

\begin{tabular}{lllllll}
\hline & Lindane & Aldrin & Endosulfan & DDE & Dieldrin & DDT \\
\hline Mean & 4.04 & 2.06 & 21.35 & 118.45 & 5.23 & 545.24 \\
SD & 3.49 & 1.48 & 3.85 & 23.41 & 2.76 & 247.06 \\
Max. & 11.76 & 4.76 & 105.58 & 814.55 & 9.74 & 905.10 \\
Min. & 1.64 & 0.61 & 1.40 & 2.18 & 1.00 & 254.26 \\
\hline
\end{tabular}


Int. J. Environ. Sci. Tech., 4 (4): 521-524, Autumn 2007

Table 2: Levels of pesticide residues in beef fat from Buoho $(\mu \mathrm{g} / \mathrm{kg})$

\begin{tabular}{lllllll}
\hline & Lindane & Aldrin & Endosulfan & DDE & Dieldrin & DDT \\
\hline Mean & 1.79 & 4.11 & 2.28 & 31.89 & 6.01 & 403.82 \\
SD & 0.38 & 8.19 & 1.74 & 21.59 & 5.14 & 276.88 \\
Max. & 2.11 & 24.32 & 6.53 & 74.57 & 15.37 & 844.28 \\
Min. & 1.24 & 0.56 & 0.40 & 12.60 & 2.21 & 37.60 \\
\hline
\end{tabular}

Table 3: Levels of pesticide residues in beef from Kumasi abattoir ( $\mu \mathrm{g} / \mathrm{kg})$

\begin{tabular}{lllllll}
\hline & Lindane & Aldrin & Endosulfan & DDE & Dieldrin \\
\hline Mean & 2.07 & 1.43 & 1.88 & 42.93 & 5.92 & DDT \\
SD & 1.31 & 0.68 & 0.42 & 9.30 & 0.05 & 18.83 \\
Max. & 2.99 & 2.34 & 2.58 & 83.60 & 3.24 & 14.78 \\
Min. & 1.14 & 0.71 & 1.45 & 5.24 & 2.50 & 108.08 \\
\hline
\end{tabular}

Table 4: Levels of pesticide residues in beef from Buoho abattoir $(\mu \mathrm{g} / \mathrm{kg})$

\begin{tabular}{llllll}
\hline & Lindane & Aldrin & Endosulfan & DDE & Dieldrin \\
\hline Mean & 0.60 & 0.73 & 0.59 & 5.86 & 11.48 \\
SD & 0.38 & 0.50 & 0.38 & 3.80 & 10.82 \\
Max. & 1.11 & 1.21 & 1.07 & 9.43 & 4.98 \\
Min. & 0.20 & 0.10 & 0.02 & 1.26 & 21.96 \\
\hline
\end{tabular}

\section{DISCUSSION AND CONCLUSION}

Results in Table 1 shows that the mean concentration of lindane in beef fat from Kumasi Abattoir is $4.04+$ $3.49 \mu \mathrm{g} / \mathrm{kg}$. Lindane was detected in 8 out of 20 (40\%) of the fat from Kumasi. The average concentration of lindane in beef fat from Kumasi was $4.04 \mu \mathrm{g} / \mathrm{kg}$. This level is below the WHO limit of $6.0 \mu \mathrm{g} / \mathrm{kg}$. Aldrin occurred in 6 out of 20 (30\%) of the samples with mean value of $2.06 \pm 1.48 \mu \mathrm{g} / \mathrm{kg}$. Endosulfan was detected in 18 out of 20 (90\%) of the samples. The mean endosulfan in beef fat in Kumasi was $21.35 \pm 3.85 \mu \mathrm{g} / \mathrm{kg}$. The highest level of endosulfan detected was $105.58 \mu \mathrm{g} / \mathrm{kg}$. DDT and, its metabolite, DDE were detected in all the fat samples analysed at a mean concentration of 545.24 \pm $247.06 \mu \mathrm{g} / \mathrm{kg}$. This sample contained the highest amount of DDT of all the samples analysed. Results in Table (2) indicate that the highest concentration of p,pDDT in beef fat from Buoho was $844.28 \mu \mathrm{g} / \mathrm{kg}$. This is about two times higher than the WHO recommended maximum residue limit of $500 \mu \mathrm{g} / \mathrm{kg}$. Endosulfan occurred in 8 out of 10 (80 \%) of the fat samples from Buoho at an average concentration of $2.28 \pm 1.74 \mu \mathrm{g} /$ $\mathrm{kg}$. The average concentration of $6.01 \mu \mathrm{g} / \mathrm{kg}$ dieldrin recorded for beef fat from Buoho is higher than the maximum level of $6.00 \mu \mathrm{g} / \mathrm{kg}$ recommended by WHO. Beef fat from Buoho registered the highest average concentration of Aldrin (4.11 $\mu \mathrm{g} / \mathrm{kg})$ and dieldrin (6.01 $\mu \mathrm{g} / \mathrm{kg}$ ) residues in them. Lindane and DDE were also detected in almost all the samples but at concentrations well below the WHO limits. The data indicate that beef fat from Kumasi Abattoir contain higher levels of lindane, endosulfan, DDE, and DDT than those from Buoho. Fat from Buoho, however, had higher levels of aldrin and its metabolite, dieldrin. The average concentrations of organochlorine residues in lean beef from Kumasi Abattoir were respectively, lindane 2.07 \pm $1.31 \mu \mathrm{g} / \mathrm{kg}$, aldrin $1.43 \pm 0.68 \mu \mathrm{g} / \mathrm{kg}$, endosulfan $1.88 \pm$ $0.42 \mu \mathrm{g} / \mathrm{kg}$, DDE $42.93 \pm 9.30 \mu \mathrm{g} / \mathrm{kg}$, dieldrin $5.92 \pm 0.0 \overline{5}$ $\mu \mathrm{g} / \mathrm{kg}$ and DDT $18.83 \pm 3.24 \mu \mathrm{g} / \mathrm{kg}$ (Table 3 ). From Table (4), the mean concentrations of organochlorine residues in lean beef from Buoho Abattoir were: lindane $0.60 \pm$ $0.38 \mu \mathrm{g} / \mathrm{kg}$, aldrin $0.73 \pm 0.50 \mu \mathrm{g} / \mathrm{kg}$, endosulfan $0.59 \pm$ $0.38 \mu \mathrm{g} / \mathrm{kg}$, DDE $5.86 \pm 3.80 \mu \mathrm{g} / \mathrm{kg}$, dieldrin $11.48 \pm 4.98$ $\mu \mathrm{g} / \mathrm{kg}$ and DDT $10.82 \pm 1.85 \mu \mathrm{g} / \mathrm{kg}$ respectively. The mean concentrations of all the residues detected in lean meat were below the WHO recommended maximum residue limits. With the exception of dieldrin, the concentrations all the other residues were higher in meat samples from Kumasi Abattior than in those from Buoho. Comparatively, the levels of the residues in all the beef fat samples were much higher than those in the lean meat. For example, the mean DDT concentration in all the fat samples was $482.04 \mu \mathrm{g} / \mathrm{kg}$ whereas that in lean meat was $14.56 \mu \mathrm{g} / \mathrm{kg}$. This, clearly, shows that DDT residues, like the other organochlorines, concentrate more in the fat than in the muscle or lean meat. The results from the study show that residues of organochlorine pesticides are present at concentrations close to the WHO Maximum 
Residue Levels (MRLs) in the meat samples. These pesticides might have originated from the feed of the cattle or from pesticides used as 'dip' to control ectoparasites on the cattle or from maternal transfer through the breast milk. Education, training and information activities on pesticides and their residues should be established and strengthened.

\section{REFERENCES}

Amoah, P.; Drechsel, P.; Abaidoo, R.C.; Ntow, W.J., (2006). Pesticide and pathogen contamination of vegetables in Ghana's urban markets. Arch. Environ. Contam. Toxicol., 50, 1-6.

Clarke, E.E.K.; Levy, L.S.; Spurgeon, A.; Calvert, I.A., (1997). The problems associated with pesticide use by irrigation workers in Ghana., Occup. Med., 47 (5), 301-308.

Ejobi, F.; Kanja, L.W.; Kyule, M.N.; Muller, P.; Kruger, J.; Latigo, A.A.R., (1996). Organochlorine pesticide residues in mothers' milk in Uganda. Bull. Environ. Contam. Toxicol., 56, 873-880.

Gerken, A.; Suglo, J.V.; Braun, M., (2001) Pesticide policy in Ghana. MoFA/PPRSD, ICP Project, Pesticide Policy Project/ GTZ. Accra, Ghana.

Hodgson, A., (2003). The high cost of pesticide poisoning in northern Ghana. Pestic. News, 62 (3), 4-8.

Jayashree, R.; Vasudevan, N., (2007), Effect of tween 80 added to the soil on the degradation of endosulfan by Pseudomonas aeruginosa. Int. J. Environ. Sci. Tech., 4 (2), 203-210.

Ntow, W.J., (2001). Organochlorine pesticide in water, sediments, crops and human fluids in a farming community in Ghana. Arch. Environ. Contam. Toxicol., 40, 557-563.

Ntow, W.J., (2005), Pesticide residues in Volta Lake, Ghana. Lakes and Reservoirs: Res. Manage., 10, 243-248.

Ntow, W.J.; Gijzen, H.J.; Drechsel, P., (2006). Farmer perceptions and pesticide use practices in vegetable production in Ghana. Pest Manage. Sci., 62 (4), 356-365.

Osafo, A.S.; Frempong, E., (1998). Lindane and endosulfan residues in water and fish in the Ashanti region of Ghana. J. Ghana Sci. Assoc., 1 (1), 135-140.

\section{AUTHOR (S) BIOSKETCHES}

Darko, G., M.Sc., Department of Chemistry, Kwame Nkrumah University of Science and Technology, Kumasi, Ghana. Email: godfreddarko@yahoo.com

Acquaah, S. O., Department of Chemistry, Kwame Nkrumah University of Science and Technology, Kumasi, Ghana. Email: sosafoacquaah@hotmail.com

This article should be referenced as follows:

Darko, G.; Acquaah, S.O., (2007). Levels of organochlorine pesticides residues in meat. Int. J. Environ. Sci. Tech., 4 (4), 521-524. 